\title{
Private Higher Education
}

\author{
by Lee A. DuBridge
}

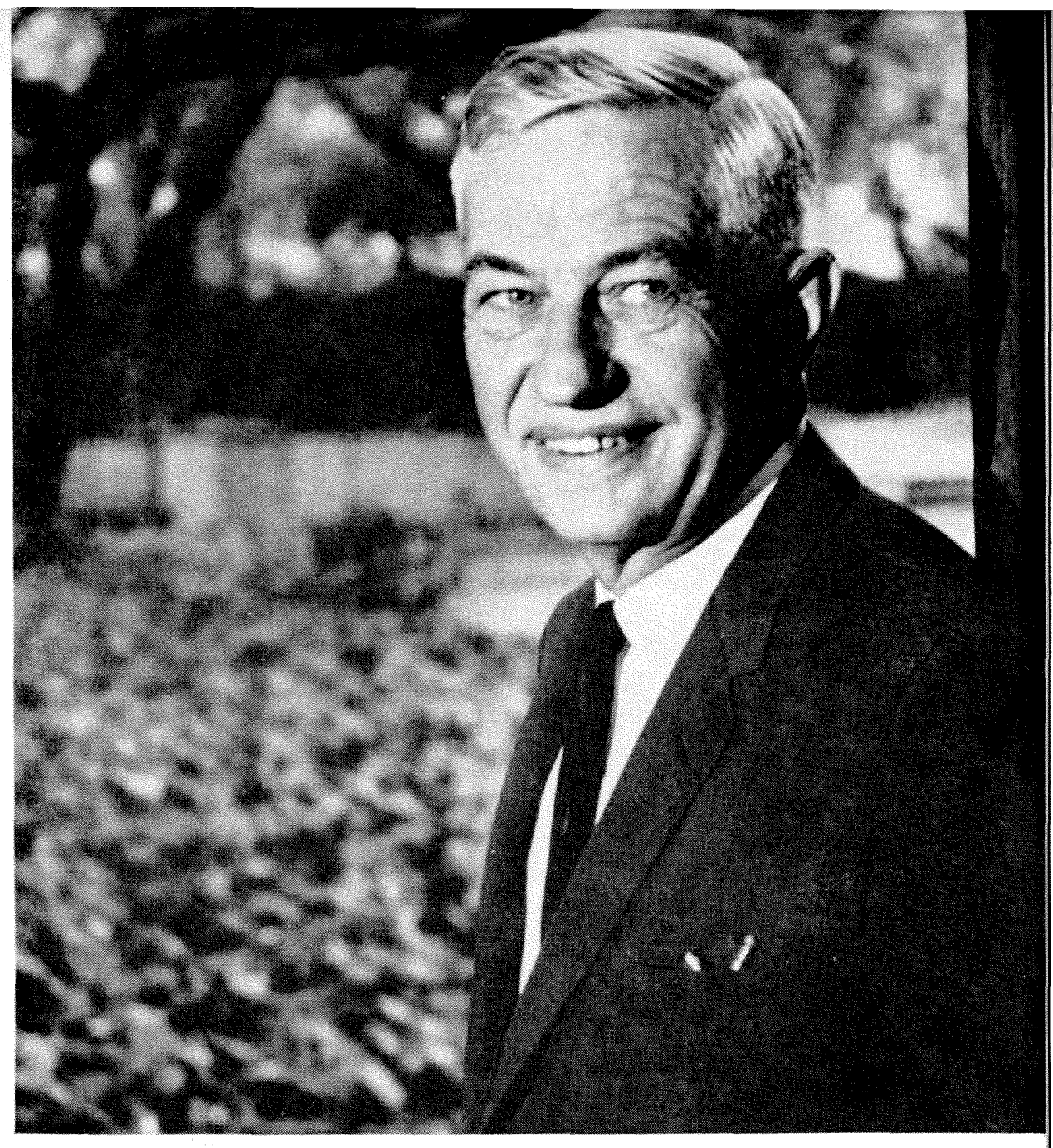

Higher education in the United States began as a private enterprise. Between the founding of Harvard in 1636 and the American Revolution in 1776, scores of private colleges were established in the American colonies to provide educational opportunity for the youth of the new nation. Most of these colleges still exist, and many of them are now among the leading colleges and universities in the world.

The first state institution, the University of North Carolina, was established in 1789, and a great period of development of state institutions began with the passage of the Morrill Act in 1862. Even so, all through the 19th century there was a spectacular growth also in the number of private colleges and universities, and even frontier communities in the Middle Western and Western states founded their colleges almost before the communities were well established.

In recent years state colleges and universities have grown so rapidly that today, in the nation as a whole, some 62 percent of the college and university students are enrolled in institutions under public control. In the state of California this figure is about 80 percent.

As the number of college students increases, not only in California but throughout the country, it is likely that publicly controlled institutions will grow in size and numbers more rapidly than the privately controlled ones - and this possibly has led many to conclude that the days of the privately controlled institution may be numbered.

Those connected with private educational institutions, however, vigorously reject this idea. While no one questions the magnificent achievements of the American system of public higher education, it is still true that our privately controlled colleges and universities form the backbone of higher education in this country. The leadership which has been shown by such world-famous institutions as Harvard, Yale, Princeton, MIT, Chicago, Johns Hopkins, Stanford, and (if you will pardon me) Caltech - to say nothing of the hundreds of liberal arts colleges - has established a pattern and a pace for higher education which has been profoundly significant throughout the history of this country, and will remain essential for the generations to come. The relative importance and influence of private institutions is not to be measured solely in terms of student enrollment.

The essential feature of any private institution is, of course, that it is wholly independent of any 


\section{The problem which faces not only the private institutions}

\section{themselves but the entire national}

community which they serve is how such

institutions can remain both independent and strong.

governmental agency - local, state, or federal. Though normally chartered by the state and subject to such public laws as are applicable, a private institution selects its own board of trustees and its own officers, and these are not responsible to any government bureau.

This means that each institution can evolve its own educational policies, adapted to fit its own objectives and ideals; it can change these policies from time to time as is deemed appropriate; and it can select both students and faculty in such numbers and to meet such qualitative standards as the institution itself may determine.

As a result of this freedom and independence, great and forward-looking advances in higher education in this country have stemmed from the independent institutions. They have pioneered and set the pace for all higher education.

\section{How an institution can remain independent}

It goes without saying that the reason an independent institution can remain independent is that its endowments, its physical plant, and its operating funds are provided largely or wholly from nongovernment sources. Private sources, even though they often give funds for designated purposes, do not normally seek to control the policies of the recipient institutions, nor impinge upon their independence. Also, the fact that such private funds usually come from many different sources (individuals, foundations, corporations) insures that no single individual or agency external to the university shall become controlling in the determination of the educational program.

A state university, by its very nature, is responsible to the state government - and, through executive, legislative, and budgetary controls, it has the power to determine institutional programs. Although most states have wisely kept their colleges and universities free from direct political influences, the institutions nevertheless are a part of the state governmental system and they cannot, and should not, forget their responsibilities to the voters and taxpayers. Our country would be much poorer if we did not have institutions with such responsibilities.

In short, both the private and public educational institutions of the country form essential parts of an integrated whole, and both components of our system of higher education deserve the continued and active support of the entire nation. These things being true, the problem which faces not only the private institutions themselves but the entire national community which they serve is how such institutions can remain both independent and strong. And this question revolves about the question of how such institutions can continue to maintain and expand their private financial support.

There have been many gloomy predictions based on the fact that, since federal tax policies now serve as barriers to building up large personal fortunes, the sources of support of private institutions will surely decline. Such predictions are not borne out by the facts.

\section{Support of private institutions}

In the first place, in spite of government tax policies, private fortunes are still being built though not, of course, in such numbers or to such great extent as if the high-income tax rates were reduced. In any case, private gifts and bequests to private institutions have not declined but have indeed continually increased.

At least 4.3 private colleges and universities have in the past nine years reported campaigns to secure private funds, ranging in amounts up to over 100 million dollars and aggregating at least 1.7 
billion dollars. The success of these campaigns surely indicates that the support of private institutions, far from withering away, is becoming stronger. The problem evidently is not that wealth does not exist, but that it is so difficult to persuade many owners to make substantial gifts for educational purposes. Colleges and universities have never been able to sit back and expect that voluntary gifts would roll in. They are secured only through energetic, continuous, and persuasive appeals.

On the other hand, the fact that such appeals have yielded large returns to many private institutions should not cause one to take too optimistic a view. While the number of dollars flowing into private institutions is greater today than ever before, these must be measured in terms of the needs and opportunities of such institutions. Measured in such terms, the funds being secured are still woefully inadequate.

\section{The rising costs of running an institution}

The costs of academic buildings have risen sharply in the last 25 years, as have also the costs for teaching and research equipment, for salaries and wages, and for all the other items that enter into the costs of running an educational institution. Many institutions are forced to restrict their enrollments because of inadequate finances. Others fail to attract their full quota of students because they have been unable to improve their facilities and staff for lack of adequate resources. Others that have adopted restricted enrollment policies for academic reasons still suffer from lack of space, equipment, and staff to continue and to improve their programs.

In spite of public impressions to the contrary, there are really no "wealthy" colleges or universities in America. Some institutions have been able to support more extensive and more expensive programs than others, but no institution has adequate funds fully to meet its goals or to fulfill its opportunities.

The problem of fund raising will thus be an ever-present and ever-urgent one as long as private institutions exist.

Fortunately, the potential bases of support for private education have expanded. Though very large gifts by individuals (e.g., one million dollars or more) are still relatively rare, there are many more individuals in the country who are making smaller gifts, and often making them on a regular basis. There are more individuals able and willing to give more than ever before and the full poten- tial of individual giving has not yet been fully tapped.

The large private foundations have always been an important source of support for higher education. The most famous ones (such as Ford, Carnegie, Rockefeller) continue as essential elements in educational support. However, their combined resources and income, even though large in dollars, are small in proportion to the total need. Fortunately, hundreds of smaller private foundations have been created, and many of these are devoting funds to higher education. In 1962 private foundations gave educational grants of over 300 million dollars.

\section{A new source of private support}

Finally, a new source of private support has arisen and has become rapidly more important in recent years - namely, the business or industrial corporation. It was only 25 years ago that corporate grants to colleges and universities were almost unknown and were considered by many to be an improper use of stockholders' money. As it has become more and more evident that business and industrial corporations in America could not survive and prosper without the contribution of the nation's colleges and universities in providing educated men and women and in contributing to the advance of knowledge, corporations and their stockholders have acquired the conviction that the support of higher education is essential to their own welfare. Court decisions have supported this point of view. In the year 1962 corporate contributions to higher education amounted to $\$ 200$,000,000 , of which approximately 75 percent, or $\$ 150,000,000$, was contributed to private institutions. (Caltech alone received over one million dollars in corporate gifts for operating funds in 1962-63.) This annual giving has risen rapidly in recent years and will surely rise still higher in the years ahead.

In short, sources of private funds for the support of higher education are by no means drying up, but are indeed expanding. It is not yet clear whether they will expand rapidly enough to meet the growing needs and increasing costs, and it is certain that many, if not most, private institutions will have to exert strenuous efforts in order to secure the funds they require. Not all will succeed; not all will even survive. This is a characteristic of the private enterprise system.

We come now to a new feature of the support of private higher education which we have so far ignored - namely, the contributions made by the 
Federal Government. This is an enormously complex subject, and the radically conflicting views which have been expressed have surely surrounded the subject with a substantial degree of confusion. There are those who have said that the activities of the Federal Government are on the verge of stamping out the independence of the private college or university. At the other extreme, there are those who assert that such institutions will be saved and their independence preserved only through the provision of federal funds. It has been both asserted and denied that there is gross waste, extravagance, and mismanagement of taxpayers' money. Some assert that federal funds have degraded the quality of higher education and others, equally vociferously, assert that quality has been vastly improved.

In evaluating the conflicting statements made on the subject, it should be recalled that it is a general rule that sweeping generalizations about any aspect of American education are never universally true in all cases and for all institutions. The American educational system is too complex and varied to be susceptible to all-inclusive assertions. Conversely, almost any statement made about education, good or bad, is probably true of some institutions or in some circumstances. One should also remember that in the field of government spending, whenever large sums are involved, there will always be charges of waste and extravagance. Whether there is proof of substantial waste or not, there will be some who will assert that in any big program waste must exist.

Putting aside sweeping and unprovable generalizations, let us look at the facts.

\section{The facts about government support}

Since 1946 there has undeniably been a rapidly rising participation on the part of the Federal Government in certain activities carried on by colleges and universities, both public and private. The great contributions made by university-operated research and development centers during World War II proved to the Government and to the people that the universities had much to contribute to national welfare and security. The Federal Government has, therefore, in effect decided through a variety of both executive and legislative decisions that the Government itself shall use the colleges and universities as instruments for the advancement of the public welfare and security by supporting in such institutions those particular activities which pertain to recognized areas of federal responsibility.
This policy of selective support of those activities related to federal responsibilities contains the key to the present situation. The Federal Government does not support higher education per se. It does not give across-the-board subsidies to colleges and universities to carry on their normal operations. In fact, there are large segments of higher education which the Federal Government specifically excludes from its support program on the ground that they are not at the present time areas of recognized federal responsibility.

\section{Government responsibility}

What, then, are the areas of recognized federal responsibility? Some of them are obvious: agriculture, public health, national defense, atomic energy, space exploration, technical assistance to underdeveloped countries. Because all of these areas depend critically upon the advance of scientific knowledge and its application, the Government's activities in the support of higher education have been almost wholly devoted to the support of the basic sciences and of medicine, agriculture, and engineering. No government funds are available for university work in the fields of the humanities (other than foreign languages). An extremely limited amount of support is available in any of the social sciences, and almost no federal support is given to the regular tasks of undergraduate education other than certain limited funds available for the purchase of scientific laboratory equipment. Graduate education and research in pure and applied science is the major area of federal participation in university activities.

Whether one likes this policy of the Federal Government or not, one must agree that it is at least a consistent policy. When the Federal Government's own activities stimulate a need for basic knowledge in scientific areas, the Government supports those activities in universities which aim to advance these fields of knowledge. When the Government's activities produce a large increase in the need for highly educated professional personnel (such as scientists, engineers, physicians) the Government, through assistance to universities and to individual students, has sought to expand the numbers being educated.

It will no doubt be true in the future, as it has been in the past, that the areas of federal responsibilities may broaden into new fields. And, when this happens, the Government's interest in university activities may be expected correspondingly to broaden.

Nevertheless, the basic fact must be kept in 
mind that the Government is not in the business of supporting higher education, but is only in the business of supporting those activities of colleges and universities which enable the Government itself to carry out more effectively its assigned functions.

Now graduate education and research in pure and applied science constitutes an important segment of higher education. This segment has in recent years been provided with substantial federal. financial support, and the level of this support has continued to rise. It is currently (in fiscal 1964) running at the rate of somewhat over one billion dollars per year.

Clearly, this money is not spread equally among all of the institutions of higher education in the country. Among the nearly 2,000 such institutions in the United States, only about 200 carry on any programs of graduate education at all, and less than 100 are in a position to carry on major research programs. Needless to say, the Government, in following its specific policy of supporting those activities in which it has a direct interest, must select those institutions where such activities can be competently and effectively carried out. Therefore, the concentration of funds in a rather small number of institutions, about which many Congressmen and others have recently complained, is a direct result of the organization of our higher educational system itself. In our system a large number of colleges carry on undergraduate work and only a relatively small number of universities have elected to enter the field of graduate education and research. It is to these institutions that the Government has turned, for they are the only institutions available to serve the Government's needs.

\section{Federal funds to scientific institutions}

Because education and research in the sciences are expensive, the result has been that those institutions able to carry on large research programs must receive relatively large sums of money. In a number of leading scientific institutions the federal funds supplied in support of education and research in scientific and engineering fields is nearly equal to the funds from all other sources expended on other university activities. For example, approximately 47 percent of the annual budget of the California Institute of Technology is supplied through federal contracts and grants for research and graduate educational programs.

This is not an unusual situation, though obviously this percentage is more likely to be high for an institute of technology than for a university with extensive activities in nonscience fields. In the academic year ending June 1961 (the latest year for which we can get comparable figures) when 47 percent of Caltech's budget came from federal funds, Stanford's corresponding figure was 46 percent, MIT's was 51 percent, Princeton's was 59 percent and Harvard's was 28 percent.

In recent years the various agencies of the Govermment and the Congress have recognized that the extension and improvement of graduate education and research cannot be fully achieved without the improvement and expansion also of undergraduate education - and even the improvement of elementary and secondary school education in mathematics and the sciences. Thus, the National Science Foundation has, for example, supported a large number of relatively small research projects being carried on by faculty members of undergraduate colleges, has assisted such colleges in improving their undergraduate instructional equipment, and has financed a large program for the improvement of course content and instructional materials for elementary and secondary schools and the concomitant retraining of schoolteachers. The new (1963) higher education act provided funds to expand undergraduate teaching facilities in mathematics and the sciences.

\section{Reaction to federal support}

How have the universities themselves reacted to these programs of federal support? Again one must avoid generalizations. Some institutions with large numbers of competent scientists and engineers on their faculties have found these individuals commanding very substantial support of their proposals for scientific research. Thus, the science departments have expanded rapidly often embarrassing the institution, which finds it difficult to provide adequate space and other facilities and services, and giving rise to unhappiness in nonscience departments since their activities seem to be receiving rather niggardly support.

Other universities, on the other hand, have found federal funds of enormous value in expanding and improving their scientific and engineering departments, and enabling them more completely to fulfill their objectives of carrying on high-quality research and education. In many cases, too, the nonscience departments are actually better off than before, since the institutions' nonfederal funds, which would otherwise be required for science and engineering, are available for other areas. 
Needless to say, government support has given rise to many problems and headaches. There have been difficulties in arriving at proper formulas for calculating the "overhead" charges which should be paid by government research contracts and grants. There have been problems of revising institutional business and auditing procedures to meet government requirements for accountability of tax funds. Then, too, some universities with large and competent staffs equipped to carry on large enterprises have been enabled to build large and expensive research equipment, such as nuclear accelerators. While these universities have faced their own problems in accommodating such large enterprises, other institutions, unable to accommodate such big projects, have found faculty members unhappy and inclined to drift to institutions where "big things" are going on. Concurrently, a few faculty members find their preferences away from "big research" and are drifting to the smaller institutions.

Undeniably, the increase in research funds has created increased demand for research scientists and engineers and the competition among colleges and universities for first-class faculty members has become very severe.

On the whole, however, the fact is that American university research in science and engineering now occupies a position of outstanding leadership in the world, a very much larger number of graduate students are being given high-quality training, and the frontiers of knowledge have been greatly extended - all by virtue of federal support. No institution engaged in major federally supported activities would wish to return to the "old days." These institutions believe - with good reason - that the headaches can be cured, that readjustments can be made, and they hope also that nonfederal funds can be found to support those educational and research areas for which federal funds are not yet available.

\section{The situation at Caltech}

In conclusion, it may be well to ask what the situation is at Caltech.

On the whole, there is much to be said on the bright side. Our endowment funds, all from private sources, now stand at about $\$ 63,000,000$. We have expended something like $\$ 29,000,000$ in new buildings and equipment in the past ten years. Our total expenses for campus operations were $\$ 17,905,000$ in $1962-63$, of which 47 percent was for research supported by federal funds.

The Caltech situation is rather unusual because of our management contract for the operation of the Jet Propulsion Laboratory for the National Aeronautics and Space Administration. In terms of annual budget (not included in the above figures), this laboratory is the largest universityoperated government facility in the country. It is carrying on an extensive program of managing NASA's deep-space unmanned flight projects and supervises extensive contracts for development work in many industrial companies. The funds expended in JPL operations, for which the Institute is reimbursed, loom large on a budget sheet but of course contribute very little directly to the financing of the campus program.

The campus program supported by the Federal Government, on the other hand, is entirely devoted to basic research in pure and applied science. All projects are originated and the funds requested by individual members of the faculty. No proposed program is approved for submission to a government agency until it is reviewed by a faculty committee, as well as by the administration, to make sure that it is an appropriate program for the campus and that the necessary space and facilities for it can be made available. In a very real sense, therefore, it can be said that the Federal Government is contributing funds for our research program which private funds alone could not support. We do not - nor does the Government expect us to - carry on military or other development programs on the campus.

\section{The problems ahead}

As we look to the future, serious problems face us. Federal funds are not available or are not adequate to carry on all the activities which we should like to pursue. Private funds must still be found to improve our general programs of undergraduate and graduate education, to support all of our work in the humanities and social sciences, and to provide most of the funds which we will require for additional urgently needed campus buildings. To meet our needs and opportunities, and their increasing costs, our endowment should be substantially expanded, our annual income from private sources must continue to grow rapidly, and millions of dollars of private funds for additional buildings must be secured.

Caltech occupies an outstanding position in the field of higher education in the United States. It can continue to maintain its relative position only as it moves forward in the future, as it has in the past, continually aiming to develop and improve its programs of education and research. 